\title{
PENTINGNYA PENGAMBILAN KEPUTUSAN DALAM MENINGKATKAN MUTU ASUHAN KEPERAWATAN
}

\author{
Dwi Syafriningsih
}

\section{Email : dwisyafriningsiih@gmail.com}

\section{Latar Belakang}

Kualitas dan efektifitas dalam pelayanan asuhan keperawatan ditentukan oleh partisipasi pasien dalam proses keperawatan. Juga membina hubungan saling percaya, menghormati dan profesional dengan mengedepankan nilai etik dan disiplin profesi. Perawat dalam melaksanakan pelayananannya menggunakan pendekatan asuhan keperawatan yang bertujuan untuk meningkatkan derajat kesehatan pasien dan keluarga dan memberikan perawatan yang profesional. Dalam memberikan asuhan keperawatan, perawat menggunakan proses keperawatan dengan lima tahapan karena dengan menggunakan proses keperawatan, asuhan menjadi komprehensif (Hariyati, 2014).

Proses keperawatan merupakan metode sistematis untuk menilai, mendiagnosis, merencanakan, melaksanakan dan evaluasi keadaan pasien dalam keadaan sehat maupun sakit sehingga menjadi dasar pemecahaan secara ilmiah, dan menjadi dasar dalam praktik keperawatan (Baraki et al., 2017). Pengelolaan yang dilakukan penting juga diperlukan untuk efektivitas kolaborasi kemajuan pasien dan mencegah perburukan kondisi pasien (Baraki et al.., 2017).

Proses pengambilan keputusan klinis merupakan komponen penting dalam proses keperawatan (Diana Catarina, 2009), sehingga dibutuhkan kemampuan perawatan karena Keterbatasan pengetahuan dan kemampuan yang dimiliki perawat dapat menghambat perawat dalam mengambil keputusan mengenai perawatan yang akan diberikan kepada klien yang akan berakibat fatal terhadap klien (Kozier et al, 2010). Mengkombinasikan nilai profesional, etik dan nilai yang di anut klien akan meningkatkan pelayanan, identifikasi kebutuhan dan masalah keperawatan lebih sistematis sehingga meningkatkan pemahaman klien dalam pengambilan keputusan asuhannya (Doheni. 1992, Potter. 2005, Jan florin. 2007). 
Proses pengambilan keputusan dalam praktik klinik keperawatan dipahami sebagai serangkaian keputusan yang dibuat oleh perawat dalam interaksinya dengan pasien mengenai jenis pengamatan yang akan dilakukan dalam situasi yang di alami klien (pengkajian keperawatan), perumusan diagnosa keperawatan, rencana tindakan keperawatan yang harus diambil, tindakan keperawatan yang akan diambil serta evaluasi (Dianan Catarina. 2009, Jan Florin. 2007, Mehee, 2014).

\section{Metode}

Metode dalam penulisan ini menggunakan metode kualitatif, yaitu merupakan metode yang sifatnya memberikan suatu penjelasan dengan analisis. Metode ini bersifat subjektif, yaitu proses penelitian yang lebih fokus pada landasan teori. Metode yang digunakan dalam kajian ini adalah Literature review. Metode ini menganalisis, eksplorasi dan kajian bebas pada artikel, jurnal, maupun ebook yang releven dan berfokus pada metode pembelajaran klinik yang mempengaruhi kemampuan pengambilan keputusan mahasiswa keperawatan. Adapun artikel yang digunakan pada literature review ini adalah artikel yang didapatkan dengan memuat 3 database Pubmed, Geogle Scholar dan Science Direct.

\section{Hasil}

Berdasarkan hasil pencarian literature didapatkan bahwa dalam mengambil keputusan dapat meningkatkan kemampuan mahasiswa untuk lebih kritis dalam mengambil keputusan dalam melakukan tindakan. Kemampuan perawat dalam pengambilan keputusan sangatla penting untuk membuat keputusan yang masuk akal tentang apa yang harus percaya dan apa yang harus dilakukan. Pengambilan keputusan klinis adalah sebuah proses yang melibatkan kedua penalaran diagnostik dan penilaian klinis. Tindakan dalam ini tindakan diarahkan sebagai proses refleksi dari perawat maupun pasien (Jan Florin, 2007).

Sebelum pengambilan keputusan tindakan, perawat harus menjelaskan terlebih dahulu mengenai pengertian, tujuan, dan pelaksanaan tindakan yang akan dilakukan dengan jelas kepada keluarga dan pasien. Apabila pasien tidak kompeten, maka keluarga terdekatnya melakukannya atas nama pasien. Banyak pasien yang menolak dan menganggap bahwa terapi-terapi yang diberikan untuk mempertahankan hidupnya bukan merupakan pilihan yang terbaik di akhir kehidupannya, untuk itu pentingnya 
perawat memahami dan menguasai mengenai pengambilan keputusan ini.

Pemberian asuhan keperawatan harus memeperhatikan klien dengan memberikan penghargaan individu meliputi preferensi, keperluan, nilai-nilai, dan memastikan bahwa semua pengambilan keputusan klinik telah mempertimbangkan dari semua nilainilai yang diingini pasien (Comite if quality of health institute of medicine 2001)

\section{Pembahasan}

Pengambilan Keputusan adalah kegiatan untuk mengumpulkan informasi dan memilih suatu tindakan dari beberapa alternatif pilihan yang tersedia, terutama yang dilakukan oleh tenaga paramedis, saat gawat darurat.

Kemampuan membuat keputusan klinik oleh perawat merupakan inti dari praktek keperawatan. Asuhan keperawatan yang diberikan oleh perawat kepada pasien menuntut perawat untuk mengambil keputusan dalam setiap tindakan dan proses keperawatan. Perawat yang tidak terampil dalam mengambil keputusan klinik tentunya akan merugikan pasien sebagai penerima perawatan dan juga turunnya mutu asuhan keperawatan. Selain fatal dan menyebabkan kematian tentunya perawat yang ragu-ragu dalam mengambil keputusan klinik akan menyebabkan lamanya perawatan pasien akan bertambah dan biaya pun akan bertambah.

Pengambilan keputusan yang baik dari perawat akan mendukung kualitas perawatan yang diberikan kepada pasien, akan tetapi jika tidak didukung dengan pengetahuan dan keterampilan yang baik dari perawat dalam melakukan pengambilan keputusan, maka akan menurunkan mutu dan kualitas dari proses keperawatan yang diberikan kepada pasien. Sehingga untuk mengatasi hal tersebut peneliti berpendapat perlu mengevaluasi kemampuan perawat untuk mengetahui sejauh mana pengetahuan dan keterampilan yang dimiliki oleh perawat untuk dapat melaksanakan kerja dengan baik.

Tahapan pengambilan keputusan

Tahap 1

Menerima tantangan. Ketika seorang prawat dihadapkan dengan tantangan, tindakan yang akan dilakukannya yaitu mengambil keputusan

Tahap 2

Mencari alternatif. Bila perawat mendapat tantangan, pengambilan keputusan yang efektif mulai mencari alternatif. Perawat 
mempertimbangkan secara matang tujuannya serta nilai-nilai yang relevan dengan suatu keputusan.

Tahap 3

Penilaian alternatif. Pada tahap ini kelebihan dan kekurangan dari masing-masing alternatif dipertimbangkan dengan cermat. Tahap ini sering melibatkan upaya yang besar untuk mencari informasi yang dapat dipercayai dengan keputusan yang efektif, mencari fakta-fakta serta dugaan sementara dari berbagai sumber yang sedang dipertimbangkan. Perawat menimbang dengan hati-hati baik aspek positif maupun negatif dari masing-masing alternatif.

Tahap 4

Menjadi terikat. Pengambilan keputusan efektif menelaah kembali semua informasi yang telah terkumpul sebelum mengambil suatu keputusan terakhir. Perawat juga memikirkan bagaimana melaksanakan keputusan dan membuat rencana cadangan jika terjadi sesuatu yang tidak diinginkan atau diluar dugaan.

\section{Tahap 5}

Berpegang pada keputusan. Setiap pengambil keputusan berharap segalanya akan berjalan lancar sesudah suatu keputusan diambil, tetapi hambatan sering terjadi. Memilih alternatif terbaik belumlah mencukupi. Jika keputusan tidak dilaksanakan secara memadai, hasil yang menggembirakan tidak akan tercapai.

Perilaku pengambilan keputusan sangat erat kaitannya dengan gaya pengambilan keputusan. Menurut Driver dan Brousseau (dalam Sudirman, 1998) terdapat dua faktor kunci yang mempengaruhi gaya pengambilan keputusan yaitu:

1. penggunaan informasi yaitu jumlah informasi yang digunakan dalam proses pengambilan keputusan

2. fokus yaitu jumlah alternatif yang diidentifikasi dan dipilih untuk mengatasi masalah.

Proses pengambilan keputusan adalah:

a. Memusatkan pikiran dan perhatian agar pasien bisa tertolong dan selamat.

b. Berpikir tentang cara-cara menolong pasien untuk melakukan tindakan. Dengan memikirkan bagaimana langkah-langkah untuk mengatasi kondisi gawat darurat, memperbaiki kondisi umum pasien. Perawat memikirkan prioritas tindakan yang harus dikerjakan berdasarkan ingatan atau informasi yang dimiliki baik dari pengalaman, pendidikan, informasi tertulis 
maupun saran dari dokter maupun rekan kerja yang lain.

c. Memikirkan resiko tindakan yang dilakukan setelah mengambil keputusan. Perawat yang sedang menghadapi masalah akan memikirkan resiko atau konsekuensi atas tindakan yang dilakukan. Misalnya ada ketakutan dari perawat, salah dalam memberikan jenis injeksi kepada pasien, yang mungkin berbeda dengan dokter. Namun ada pula yang bertindak tidak memikirkan resikonya, namun setelah tindakan itu selesai dilakukan baru memikirkan resikonya.

d. Berpikir menghubungi orang lain (dokter) untuk meminta bantuan. Terdapat beberapa perawat yang berpikir untuk segera mencari bantuan kepada orang lain. Dalam hal ini dokter untuk membantu menghadapi kasus pasien.

e. Tidak memikirkan sesuatu, karena sudah menjadi rutinitas. Tindakan terhadap pasien gawat darurat berdasar pengenalan masalah sudah berlangsung.

Ketepatan pengambilan keputusan akan di pengaruhi oleh kompentisi perawat, kemampuan berkomunikasi, lingkungan serta budaya. Penting bagi perawat untuk selalu meningkatkan kualitas dirinya dalam pemberian asuhan keperawatan. Hal ini akan meningkatkan kepercayaan masyarakat atau

pasien terhadap perawat yang selanjutnya akan meningkatkan profesionalisme perawat. Hal ini bisa digunakan sebagai acuan dalam melakukan hubungan interdisiplin.

Pengambilan keputusan yang tepat akan meningkatkan kemandiran klien dalam asuhannya serta membantu klien untuk menentukan pilihan bantuan yang tepat sesuai dengan kondisinya. Klien yang mandiri akan menurunkan beban kerja perawat sehingga pelayanan keperawatan akan lebih efektif dan efisien dalam penggunaan sumber daya.

\section{Penutup}

\section{Kesimpulan}

Pengambilan keputusan yang baik dapat meningkatkan mutu asuhan keperawatan. Kualitas perawatan yang baik diberikan oleh perawat kepada pasien, dengan mempertimbangkan keputusan yang diambil, agar tidak terjadi hal-hal yang tidak diinginkan. Perawat harus memiliki pengetahuan dan juga keterampilan dalam mengambil keputusan, agar kepututsan yang diambil tidak memeiliki resiko negatif kepada pasien.

\section{Saran}


Mengingat pentingnya pengambilan keputusan dalam meningkatkan asuhan keperawatan, maka direkomendasikan agar perawat memiliki pengetahuan luas, kesigapan serta pengalaman yang baik agar dapat mengambil suatu keputusan yang tepat.

\section{DAFTAR PUSTAKA}

Erianti, S. Machmud, R. Harmawati. (2019). Determinan Pengambilan Keputusan Klinik Keperawatan di RSUD Arifin Achmad Provinsi Riau. Jurnal Kesehatan Komunitas. Vol. 5(3). 227-234.

Fortunatti, CFP. (2014). Most important needs of family members of critical patients in light of the Critical Care Family Needs Inventory. Invest Educ Enferm ; 32(2): 30616.

Hafifah, I. Fithriyah, N. (2018). PENGALAMAN KELUARGA DALAM PENGAMBILAN KEPUTUSAN PADA PASIEN KRITIS DI RUANG INTENSIVE CARE UNIT (ICU) RSUD ULIN BANJARMASIN. Dunia Keperawatan, Volume 6(1). 11-18.

Hariyati, R. T. S. \& Safril, S. (2018). The relationship between nurses' job satisfaction and continuing professional development. Enferm Clin, 28(1). 144-148.

Ignatavicius, D.D. (2001). Crtical Thinking Skill For At The Bedside Success. Nursing Manajement, 32 (1), 37-39.

Khairina. Ifa, Hema Malini, Emil Huriani. (2018). Faktor-Faktor yang Berhubungan dengan Pengambilan Keputusan Perawat Dalam Ketepatan Triase Di Kota Padang. Indonesian Journal For Heath Science. Vol 2(1).

Kozier, B,. et al. (Ed.7). (2010). Bukuajarfundamental keperawatan : konsep, prosesdan praktik keperawatan. Jakarta: EGC

Potter, Patricia A. (2005). Fundamental of Nursing: Concepts, Proses adn Practice 1st Edition. Jakarta: EGC.

Purwati, E. Nuryadi. Herawati, Y. (2017).

Pengambilan Keputusan dalam Pelaksanaan Rujukan Puskesmas sebagai Fasilitas Kesehatan Tingkat Pertama. e-Jurnal Pustaka Kesehatan. Vol. 5(2). 231-238.

Simamora, R. H. (2019). Menjadi perawat yang: CIH'HUY. Surakarta: Kekata Publisher.

Simamora, R. H. (2005). Hubungan Persepsi Perawat Pelaksana Terhadap 
Penerapan Fungsi Pengorganisasian Yang

Dilakukan Oleh Kepala Ruangan Dengan

Kinerjanya Diruang Rawat Inap RSUD

Koja Jakarta Utara (Doctoral dissertation, Tesis FIK UI, Tidak dipublikasikan).

Tedjomuljo dan Afifah. (2016). Tingkat

Pengrtahuan Mahasiswa Keperawatan

Tentang Kode Etik Profesi dan Caring.

Jurnal Keperawatan Indonesia, 19(2),129-

136. 